\title{
Nilai Organologi Akustik Polopalo
}

\author{
Rahmawati Ohi \\ Staf Pengajar Sendratasik Fakultas Sastra dan Budaya Universitas Negeri Gorontalo \\ Email : 08rahmawatiohi@gmail.com
}

\begin{abstract}
Abstrak
Nilai merupakan makna, pesan baik secara implisit-ekspilit berupa gagasan atau teori yang bekerja dalam aktivitas masyarakat, salah satu obyek material yang menggambarkan fenomena itu adalah alat musik tradisi. Berbicara alat musik tradisi maka terdapat salah satu yang benilai adiluhung yaitu Polopalo. Polopalo merupakan alat musik perkusi, ikon Gorontalo dengan keunikan organologi yang mirip dengan mulut buaya dan menghasilkan karakter bunyi akustik yang khas. Aspek organologi akustik Polopalo yang unik dan menarik menjadikan fungsi nilainya terus mengalami perkembangan dan transformasi dalam aktivitas masyarakat dan dunia ilmu pengetahuan.

Nattiez tentang proses pemaknaan pada tiga tataran: penguraian komponen akustik, latar belakang sejarah atau budaya serta respon fisio-akustik serta di dukung oleh teori Alperson-Bordieu sehingga dalam metode penelitian menggunakan kuantitatif-kualitatif.

Hasil penelitian menunjukkan bahwa nilai organologi akustik Polopalo merupakan perwujudan dari karakter dan filosofi masyarakat Gorontalo dalam kehidupan sehari-hari yang eksistensi tandanya diwakili oleh frekuensi dan interval bunyi yang unik.
\end{abstract}

\section{Kata kunci : Nilai, organologi akustik, Polopalo}

\section{Abstract}

Values are meanings, messages either implicitly-exemplified in the form of ideas or theories that work in community activities, one of the material objects that describe the phenomenon is a traditional musical instrument. Speaking of traditional musical instruments, there is one that is valuable, namely Polopalo. Polopalo is a percussion instrument, a Gorontalo icon with a unique organology that is similar to a crocodile's mouth and produces a distinctive acoustic sound character. The unique and interesting aspect of Polopalo's acoustic organology makes its value function continue to experience development and transformation in the activities of society and the world of science.

Nattiez about the meaning process at three levels: decomposition of acoustic components, historical or cultural background and physio-acoustic response and supported by the Alperson-Bordieu theory so that the research method uses quantitative-qualitative.

The results showed that the value of Polopalo's acoustic organology is the embodiment of the character and philosophy of the Gorontalo people in everyday life where the existence of the sign is represented by the unique sound frequency and interval.

Keywords: Value, acoustic organology, Polopalo 
A. Pendahuluan

Nilai merupakan makna, pesan atau sistem baik secara eksplisit maupun implisit berupa konsep, gagasan ataupun teori sehingga bermakna secara fungsional dalam aktifitas masyarakat dalam konteks iptek dan kebudayaan. Berbicara tentang nilai, maka obyek material yang secara eksplisit-implisit berisi pesan makna yang berupa konsep, gagasan dan teori bersifat adiluhung adalah alat musik tradisi.

Alat musik tradisi nusantara merupakan salah satu karya seni yang bernilai adiluhung, modern teknologi, dan mempunyai keunikan dalam aspek organologi akustik yang dihasilkan. Sebagai sebuah karya seni, alat musik dinilai bekerja ketika fungsinya mampu memposisikan diri dalam menginduksi, memberi pengembangan keragaman pada kemapanan dunia ilmu pengetahuan, kehidupan masyarakat tanpa melepaskan jati dirinya sebagai karya seni serta timbal baliknya terhadap eksistensi alat musik sendiri. Salah satu alat musik tradisi yang mempunyai keunikan organologi akustik adalah Polopalo
Membicarakan tentang Polopalo, Bay (dalam Ohi, 2014: 1) menjelaskan bahwa polopalo merupakan alat musik kebanggaan dan ikon masyarakat Gorontalo sedangkan tinjauan aspek organologi mengklasifikasikan Polopalo sebagai instrumen perkusi pentatonisyang memiliki bentuk seperti mulut buaya terbuka dan terbuat dari bambu khusus (talilo huidu) atau bamboo gunung. Pemilihan talilo huidu sebagai bahan Polopalo dikarenakan mempunyai kadar air yang rendah sehingga mampu menghasilkan kualitas bunyi yang baik

Saud (dalam Ohi: 2014) menjelaskan bahwa bunyi Polopalo diperoleh dari getaran badannya, yaitu dari rahang dan lidah yang mirip dengan mulut buaya dimana memperoleh bunyi ditentukan dengan cara meraut rahang dan lidah polopalo. Saud menambahkan bahwa dalam memainkan polopalo memerlukan sebuah alat bantu yaitu tongkat kecil yang dilapisi oleh tali yang terbuat dari karet yang nantinya sebagai wadah pukulan. Jenis Polopalo ada empat yaitu motoliyongo, modulodu'o, moelenggengo dan mobulongo.

Perkembangan polopalo sekarang ini mengalami pasang surut, dimana 
adanya usaha mengembangkan polopalo menjadi instrumen diatonis tetapi belum memahami polopalo yang pentatonis. Permasalah ini menjadi rumit, ketika instrument polopalo pentatonis mulai tergeser padahal secara akustik, polopalo jenis pentatonis dianggap sudah cukup mewakili filosofi masyarakat Gorontalo.

\section{Music and Discourse}

Nattiez (1990) dalam Music and Discource memberikan penjelasan bahwa semiologi musik merupakan bagaimana musik bekerja di dalam masyarakat sehingga proses semiosis menjadi tiga tahapan. Tahap pertama adalah menganalisis struktural musik, dalam hal ini sudut pandang fisika dipergunakan sebagai pisau bedah dalam menganalisis komponen seperti frekuensi, amplitude dan unsur di dalamnya. Tahap kedua adalah latar belakang budaya dan konteks perbedaan struktural berdasarkan ranah sejarah ataupun antropologis, etnomusikologis, budaya sedangkan tahapan ketiga adalah proses kognitifperceptual yang dipergunakan ketika orang membangun pemahaman, terjadi pada tataran ilmu psikologis.

\section{Relasi Hanslick dan Bordieu}

Hanslick (dalam Alperson: 1994) menjelaskan bahwa konsep produksi suara atau bunyi berkaitan dengan makna dari sebuah sumber bunyi. Makna bunyi berkaitan dengan elemen musical yang dapat memberikan sensasi pada pendengar, berkaitan dengan ekspresi yang dihasilkan. Hanslick menambahkan bahwa makna musik berhubungan dengan budaya masyarakat yang membentuk, musik merupakan mimesis dari alam dan ekspresi gambaran aktivitas budaya masyarakat.

Bordieu (1990) memberikan uraian singkat mengenai tindakan sosial bagian dari kebudayaan, dimana struktur tindakan tersebut dapat berdiri sendiri ataupun dipertukarkan. Negosiasi budaya berasal dari kesadaran habitus yang tidak lain adalah nilai-nilai sosial yang dihayati manusia dan proses sosialisasinya menjadi berpikir dan pola perilaku dalam diri manusia. Habitus menyebakan manusia menghasilkan kapital atau modal baik modal ekonomi atau budaya, dimana modal menghasilkan arena atau ruang khusus dengan timbal balik bahwa 
kesuksesan arena dipengaruhi oleh modal dan habitus.

\section{Metode Penelitian}

Penelitian ini menggunakan kuantitatif-kualitatif, dimana pengumpulan data kuantitatif dilakukan melalui pengukuran untuk mengetahui karakter bunyi yang dihasilkan melalui frekuensi, sedangkan kualitatif adalah aspek latar belakang sejarah atau budaya dimana menjadi wilayah etnomusikologi. Analisis data pada tahapan kualitatif menggunakan analisa domain karena polopalo mempunyai peranan dalam kebudayaan masyarakat Gorontalo. Creswell (2011) menjelaskan bahwa kode-kode verbatim dalam penelitian kualitatif memberikan informasi tentang aktivitas masyarakat.

\section{Hasil dan Pembahasan}

Masyarakat Gorontalo lebih popular menyebut frekuensi sebagai bahasa untuk mempersepsikan akustik bunyi tinggi atau rendah polopalo, mereka tidak mengenal pitch. Fakta ini merupakan bentuk metaphor habitus masyarakat Gorontalo dalam memahami dan mengintepretasikan aspek-aspek dalam memahami sebuah makna obyek terutama kualitas bunyi. Intepretasi kognitif masyarakat terhadap frekuensi untuk menggambarkan akustik bunyi tinggi atau rendah dipengaruhi oleh faktor budaya, sehingga untuk memberikan bukti karakter akustik bunyi Polopalo yang mampu menjadi landasan dan bersifat obyektif dilakukan pengukuran

\begin{tabular}{|c|c|c|}
\hline Jenis Polopalo & Frekuensi Fundamental (Hz) & Interval (cents) \\
\hline Moelenggengo & 389 & \\
\hline Mobulongo & 480 & 363,917 \\
\hline Modulodu'o & 511 & 108,36 \\
\hline Motoliyongo & 536 & 82,691 \\
\hline
\end{tabular}


Berdasarkan hasil pengukuran diperoleh bahwa frekuensi fundamental polopalo tipe moelenggengo adalah 389 Hz. Hasil pengukuran sesuai dengan persepsi masyarakat mengenai bunyi polopalo tipe moelenggengo, dimana masyarakat mempersepsikan sebagai bunyi yang tidak nyaring, menggelepar, bunyi dengan frekuensi rendah. Frekuensi fundamental untuk motoliyongo sebagai polopalo dengan bunyi nyaring diperoleh nilai $536 \mathrm{~Hz}$, paling tinggi. Hal ini sesuai dengan persepsi masyarakat ketika mendengar bunyi motoliyongo yang dipersepsikan sebagai bunyi nyaring dan bagus dengan frekuensi paling tinggi. Salah satu keunikan dari polopalo jenis pentatonik ternyata mempunyai interval atau jarak bunyi yang semakin kecil diantara akustik bunyi yang tinggi.

\section{Nilai akustik bunyi polopalo}

Konteks sistem budaya masyarakat Gorontalo, bunyi sebuah instrumen selalu berkaitan dengan suasana dan kondisi masyarakat seperti bunyi polopalo. Motoliyongo digambarkan sebagai bunyi polopalo yang melengking, seperti suara burung pipit yang bermakna jiwa besar, ingin dikenal orang, pemberani, cerdik lincah. Ditinjau dari aspek suasana menggambarkan perasaan gembira karena awal datangnya hari. Bunyi modulodu'o merupakan bunyi polopalo yang berdetak-berdetak seperti suara burung gagak menandakan kondisi tidak aman. Bunyi modulodu'o berarti ingin berkuasa dan siap menantang. Bunyi mobulongo merupakan bunyi polopalo yang menggaung berarti berjiwa tenang, sederhana dan menghindari tantangan, di ibaratkan seperti suara kokok ayam jantan yang menandakan masyarakat yang tenang sedangkan bunyi Moelenggengo merupakan bunyi polopalo yang berdencing diibaratkan suara burung kakaktua yang bermakna hidup penuh persahabatan.

Namun dalam perkembangannya juga terdapat relasi makna dan bunyi Polopalo dalam konteks sifat atau tingkah laku masyarakat. Bunyi motoliyongo memiliki elemen frekuensi yang paling tinggi yang berhubungan dengan tata cara masyarakat Gorontalo ketika berbicara, halus dan berkarakter, motoliyongo dihubungkan dengan suara burung 
Tonggulalahe (sejenis burung pipit berwarna kuning) menandakan suasana gembira dan waktu terbitnya matahari. Bunyi moelenggengo atau mokalubebe memiliki frekuensi paling rendah, berkaitan dengan cara berbicara cepat dan jelas, dihubungkan dengan suara burung kakatua (nuri) menyatakan suasana masyarakat yang penuh persahabatan. Bunyi mobulongo memiliki frekuensi lebih tinggi dari moelengenggo, yang berhubungan dengan vokal dari setiap kata banyak menggunakan huruf $\mathrm{O}$ contohnya, mohelumo, mohuyula dsb, moelenggengo dikaitkan pula dengan kokok ayam jantan yang menyatakan kondisi masyarakat tenang penuh kedamaian. Bunyi modulodu'o memiliki frekuensi dibawah motoliyongo sangat erat kaitannya dengan kehidupan masyarakat yang kuat dan mampu menghadapi segala tantangan dihubungkan dengan suara burung gagak $\left(\mathrm{Pa} \mathrm{o}^{\prime}\right)$ menyatakan suasana ataupun kondisi masyarakat tidak aman.

Polopalo adalah musik tradisi Gorontalo yang erat kaitannya dengan tatanan kehidupan masyarakat Gorontalo, suka bekerja keras tidak mengenal lelah, hidup bergotong royong dan saling menghargai satu sama lain. Makna masing-masing bunyi polopalo yang ada di dalam masyarakat Gorontalo erat hubungannya dengan filsafat alam. Filsafat alam bagi masyarakat Gorontalo merupakan hal yang bersifat mengikat, masyarakat mempercayai bahwa alam merupakan hal mendukung dalam aktivitas kehidupan sehari-hari. Dari suara alam, masyarakat menstransferkan ke dalam bunyi polopalo sampai terbentuklah makna bunyi yang sampai sekarang masih menjadi pedoman dalam membuat polopalo. Bagi masyarakat Bone Bolango, istilah bunyi nyaring dan tidak nyaring merupakan ungkapan dalam mendengar bunyi polopalo. Bunyi nyaring bagi masyarakat Bone Bolango identik dengan frekuensi tinggi, sedangkan bunyi tidak nyaring identik dengan frekuensi rendah. Hal ini merupakan sebuah bentuk methapor dari persepsi, pemikiran masyarakat dalam memahami dan mengintegrasikan bunyi polopalo yang dipengaruhi oleh sistem budaya masyarakat.

Kesamaan antara hasil persepsi masyarakat terhadap elemen frekuensi 
polopalo dengan hasil pengukuran empat jenis polopalo membentuk sebuah metaphor yang berupa persepsi, pemikiran masyarakat yang secara obyektif mampu mengintepretasikan bunyi polopalo yang didengar, sesuai dengan hasil pengukuran. Hal ini merupakan bentuk metaphor dalam bentuk pemikiran dalam mempersepsikan elemen bunyi yang didengar yang dipengaruhi oleh faktor budaya. Persepsi dan intepretasi masyarakat terhadap bunyi nyaring dan bunyi tidak nyaring yang berkaitan dengan frekuensi tinggi dan frekuensi rendah mengandung makna bahwa bunyi polopalo mampu memberikan sensasi dan berhubungan filosofi masyarakat. Bagi masyarakat Gorontalo yang mengenal filsafat alam, dimana bunyi polopalo dimimesiskan dengan suara makhluk hidup yang mempunyai arti filosofi kehidupan masyarakat.

Ditinjau melalui teori Alperson (1994) bahwa elemen frekuensi polopalo merupakan pusat perhatian dari instrumen tersebut, karena berkaitan dengan proses sensasi mendengar bunyi nyaring ataupun tidak nyaing yang berkaitan dengan unsur frekuensi bunyi polopalo. Sensasi yang dirasakan dalam mendengar sebuah bunyi merupakan langkah awal dalam memahami makna bunyi, proses mendengarkan bunyi polopalo bagi masyarakat memberikan sensasi yang cukup bervariasi, antara lain; elemen bunyi polopalo jenis motoliyongo dan moelenggengo mampu digunakan sebagai hiburan, sebagai pengantar tidur, mengingatkan mereka sewaktu masa kecil dan sebagai penghilang rasa penat. masyarakat merasakan bahwa bunyi polopalo hadir melalui elemen frekuensinya sehingga mereka dapat membedakan masingmasing karakter bunyi polopalo. Sensasi dalam mendengar bunyi adalah nilai filosofi yang membentuk karakter polopalo baik dari sisi instrumen maupun bunyi. Bunyi polopalo berasal dari bambu yang digetarkan. Bagi masyarakat Gorontalo bambu memiliki makna yaitu mudah hidup, mudah tumbuh. Maksud makna mudah hidup dimana bambu merupakan tanaman yang menggambarkan kerukunan hidup dalam masyarakat. Mudah tumbuh memiliki penjelasan bahwa masyarakat Gorontalo mempercayai tatanan keluarga yang 
merupakan aspek awal dari kehidupan masyarakat. Bahan bambu sebagai dasar dari pembuatan polopalo berkaitan dengan bunyi yang dihasilkan. Dalam masyarakat Gorontalo polopalo memiliki empat jenis bunyi dan sensasi bunyi yang berbeda. Berdasarkan hasil analisis domain bunyi polopalo memiliki makna filosofi yang diadaptasi oleh jenis aktifitas sosial. Masyarakat Gorontalo menganut filsafat alam dimana masyarakat percaya pada ciri-ciri perubahan alam yaitu adanya bendabenda (mahluk) sekitar yang dianggap memberikan makna tertentu. Ada empat jenis bunyi polopalo yakni; motoliyongo, moelenggengo, modulodu'o dan mobulongo dari ke empat jenis bunyi polopalo tersebut memiliki makna filosofis masyarakat Gorontalo.

\section{Simpulan}

Nilai organologi akustik Polopalo merupakan manifestasi dari karakter dan filosofi masyarakat Gorontalo dalam kehidupan sehari-hari yang eksistensi tandanya diwakili oleh frekuensi dan interval bunyi. Pembagian jenis polopalo menjadi empat nama merupakan representasi dari tatanan kehidupan, arena, modal sifat dan habitus masyarakat dalam menjalani aktifitas sehari-hari.

\section{Daftar Pustaka}

Alperson, Philip. 1994. What a music? An Introduction to the Philosophy of Music. University Park. PA: Pennsylvania State University Press.

Bay, Suwardi. 2009. Musik Tradisional Polopalo. Catatan, Tidak Terbit.

Bordieu, Pierre. 1990. Essay; Toward a Reflexive Sociology. Cambridge Publishity Press.

Creswell, Jhon. 2012. Research Design, Pendekatan Kualitatif, Kuantitatif dan Mixed terjemahan Achmad Fawaid: Pustaka Pelajar. Yogyakarta.

Nattiez, Jean. 1990. Music and Discourse: Toward a Semiology of Music. Princeton University Press 